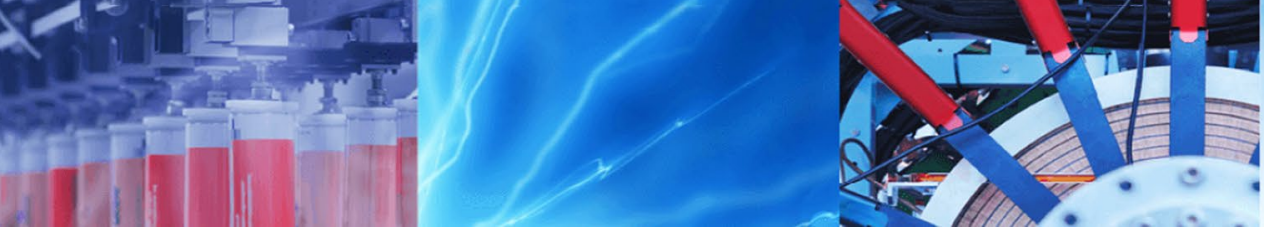

Research Article

\title{
Ecological and human health exposure risks to heavy metals in Oji River sediments: effect of abattoir and power station
}

\author{
Uzochukwu Cornelius Ugochukwu ${ }^{1}$. Amaka Lynda Onuorah ${ }^{1}$ - Virginia U. Okwu-Delunzu ${ }^{2}$. \\ Ujunwa L. Odinkonigbo ${ }^{1}$. Onyechi Henry Onuora ${ }^{1}$
}

(c) Springer Nature Switzerland AG 2019

\begin{abstract}
In this study, the ecological and human health exposure risks due to the effects of abattoir and power station on heavy metal input into the sediments of Oji River in Enugu State Nigeria were assessed. Heavy metals in the sediments were measured using atomic absorption spectrometry. Pollution of the sediments was assessed using: contamination factor (CF), degree of contamination (CD), geochemical accumulation index $\left(I_{\text {geo }}\right)$ and pollution load index (PLI), whereas the ecological risk was assessed using potential ecological risk index. Non-carcinogenic risks of exposure by humans to the heavy metals were assessed using hazard index. Obtained results indicate that the abattoir contributed to heavy metal input into the sediments significantly (unlike the power station) and most likely due to the use of waste tires at the abattoir as fuel. All pollution parameters (CF, CD, I geo and PLI) reveal that pollution of the sediment with heavy metals around the abattoir is most profound and the ecological risk of heavy metals in the sediments is very high. Non-carcinogenic risk of exposure to heavy metals due to inadvertent ingestion and contact with sediments is insignificant.
\end{abstract}

Keywords Ecological risks $\cdot$ Heavy metals $\cdot$ River $\cdot$ Risk assessment $\cdot$ Sediment

\section{Introduction}

Rivers are one of the most common sources of fresh water and provide ecosystem services that are beneficial to man and other living organisms, especially aquatic organisms. For ecosystem functioning of rivers to operate sustainably, the dynamics of the biological and physicochemical characteristics of the rivers must be within the resilience abilities of all the community structures of the river; otherwise, unacceptable changes could take place. For example, activities of man can alter the biological and physico-chemical properties of rivers in such a manner that could bring about changes in aquatic ecology and water use patterns by humans [35]. It has been reported that changes in the riverine processes and aquatic ecology may manifest in several ways such as reduced biodiversity and productivity, altered plant community structure and behavior, reduced resilience to invasive species and altering river vertebrates and invertebrates community structure $[7,15]$.

Heavy metals are common environmental pollutants arising mainly from increased anthropogenic activities and pollute rivers as they partition into water column and sediments $[2,9,10]$. Greater proportion of the heavy metals is partitioned onto the bed sediments with a little proportion remaining in the water phase [12]. Hence, it has been reported that under certain circumstances, over $90 \%$ of the heavy metals entering a water body enter sediment bound rather than freely in the water phase [31].

The ecological importance of sediments cannot be over-emphasized as they act as both sinks and reservoirs for environmental contaminants such as heavy metals. If

\footnotetext{
$\triangle$ Uzochukwu Cornelius Ugochukwu, uzochukwu.ugochukwu@unn.edu.ng| ${ }^{1}$ Shell/UNN Centre for Environmental Management and Control, University of Nigeria, Enugu Campus, Enugu, Nigeria. ${ }^{2}$ Department of Geography and Meteorology, Faculty of Environmental Sciences, Enugu State University of Science and Technology, Agbani, Enugu State, Nigeria.
} 
heavy metals accumulate beyond a certain level in sediments, they could cause ecological mayhem. Monitoring ecological risks in sediments from heavy metals is therefore extremely important and could be achieved via the estimation of geoaccumulation index [25], pollution load index and ecological risk index [14].

Oji River itself as a water body is a tributary of Anambra River, the main tributary of the lower Niger River. Oji River which is the focus of this study is extremely important because of several anthropogenic activities around the river at several locations that could impact on the aquatic ecology of the river. Abattoir where waste tires are burnt as fuel used in the preparation of hide and skin from slaughtered cows is located very close to the Oji River. Also located close to the Oji River is a power station that distributes electricity to over 500,000 households within Enugu State.

The locals within the riverside use the water for bathing, washing and cooking and therefore could be exposed to the carcinogenic or non-carcinogenic health effects of some heavy metals. Heavy metals such as cadmium, lead and chromium are reported to have both carcinogenic and non-carcinogenic health effects, whereas others such as zinc, aluminum, copper have non-carcinogenic health effects $[18,24]$. It is therefore extremely important to assess the seasonal exposure risks of the water users for the aforementioned purposes.

The release of heavy metals as environmental contaminants and consequent pollution of nearby rivers and soil arising from the operation of power generating plants is well reported $[3,11,17]$. However, there are hardly studies showing whether or not power distribution stations release heavy metals that could pollute a nearby river (that acts as a receptacle to the station's wastewater) to the extent of posing significant health and ecological risks.

Studies on the release of heavy metals into river sediments arising from the activities of power station and an abattoir (where waste tires are used as fuel for burning off cows' hairy skin as practiced in most developing countries such as Nigeria) are not well reported. It is therefore not known whether heavy metal input from an abattoir using waste tires as fuel poses any significant ecological and health risks.

This study shall assess pollution of Oji River sediments by heavy metals arising from abattoir and power plant activities using contamination factor, degree of contamination, geochemical accumulation index, pollution load index and potential ecological risk index. Contamination factor (CF) is a very useful tool in identifying the contamination level of sediments by the individual heavy metals. Because the degree of contamination (CD) considers all the measured heavy metals, it is useful in estimating the cumulative level of contamination. The geochemical accumulation index $\left(I_{\text {geo }}\right)$ provides a measure of the extent of the heavy metal contamination compared to background levels. It therefore provides evidence for anthropogenic releases of the heavy metals in the sediments. Pollution load index (PLI) is a good tool used in estimating the extent of pollution of the sediments. The potential ecological risk index (PERI) estimates risks posed to biota inhabiting the sediments from the heavy metal pollution of the sediments.

The objectives of this study therefore are to:

- Evaluate the concentration of heavy metals in the sediments of Oji River around the locations of an existing abattoir and Oji River Power Station

- Estimate ecological risks arising from the presence of the heavy metals in the sediments impacted by the activities of the abattoir and the Oji River Power Station

- Estimate non-carcinogenic risk of exposure to humans who make contact with the sediments

\section{Materials and methods}

\subsection{Study area}

The study area, shown in Fig. 1, is in Oji River Local Government Area (LGA). The Oji River LGA with a landmass of about $400 \mathrm{Km}^{2}$ and a population of 126,587 as at the 2006 population census is located geographically between latitude $6^{\circ} 14^{\prime} \mathrm{N}$ and $6^{\circ} 20^{\prime} \mathrm{N}$ and between longitude $7^{\circ} 17^{\prime} \mathrm{E}$ and $7^{\circ} 21^{\prime} \mathrm{E}$. The geology of the area comprises 330-m-thick Ajali formation that is underlain by $400-m$-thick Mamu and 200-m-thick Nkporo formations. These Ajali, Mamu and Nkporo formations are characterized by sandstone, sandy shale and mudstone, respectively $[27,30]$. Rainy season (April-October) and dry season (November-March) are the two seasons in Nigeria especially the southern part of Nigeria where the study area is located. Rainfall at its peak can be quite heavy with several incidents of flooding that leave gully erosion in its trail [8]. The river is a fastflowing one that receives waste discharges from several anthropogenic activities such as abattoir, power plants, agricultural runoff. The study area and sampling locations are as presented in Fig. 1.

\subsection{Sampling}

The sampling campaign for this study took place in October 2017 and January 2018 to cover both the wet and dry seasons. Samples were collected forthrightly each month in triplicate from locations shown in Fig. 1. The sampling locations were carefully selected to isolate effect of discharges from two major different activities, viz., abattoir 

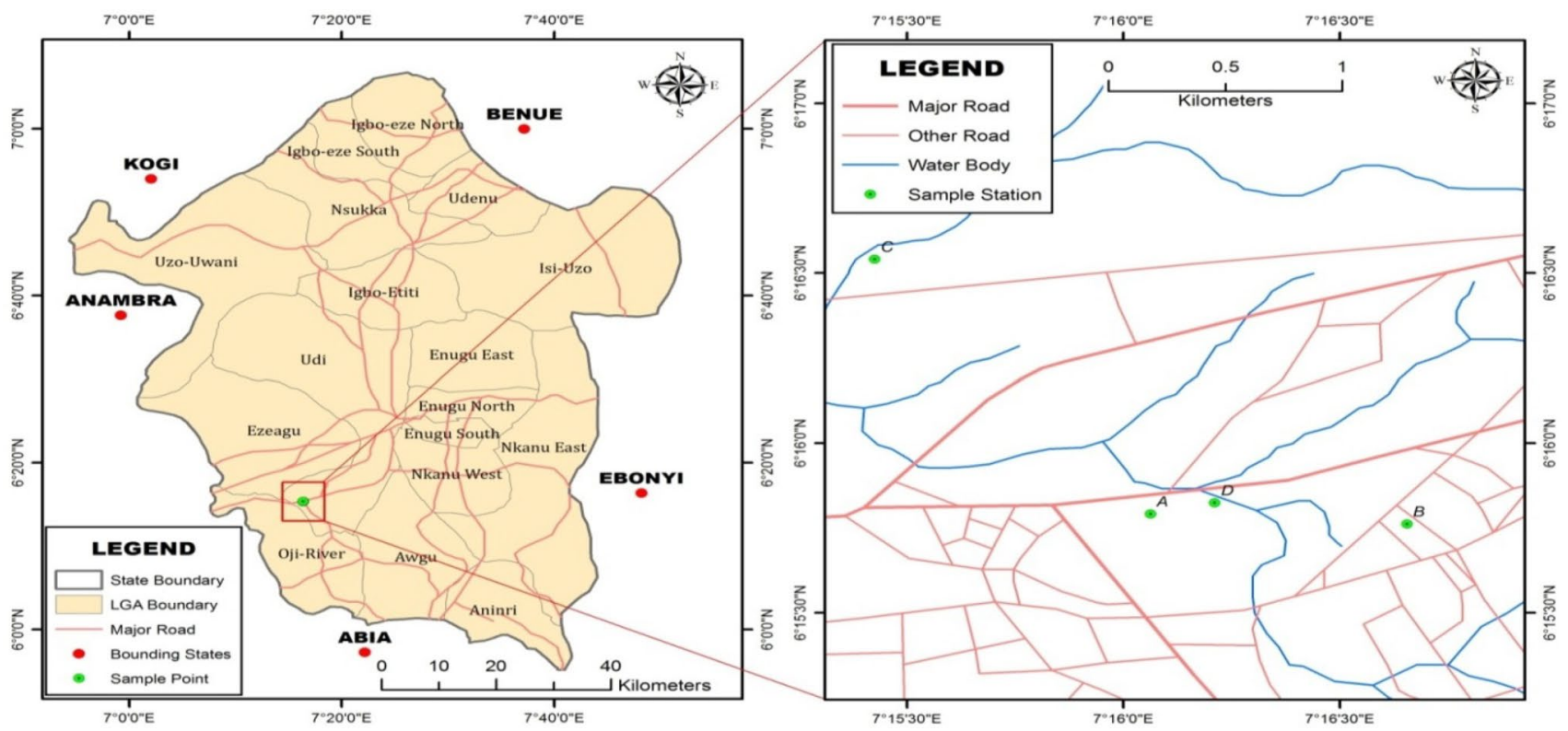

Fig. 1 Map of the study area showing sampling locations, $A, B, C$ and $D$, covering a distance of about $0.75 \mathrm{~km}$

and the power station. Sampling location $A$ is about 250-m upstream the abattoir, while sampling location $B$ is within the discharge point of wastewater from the abattoir. Sampling location $C$ is about 250-m downstream the abattoir and about $100-\mathrm{m}$ upstream the power station. Sampling location $D$ is about $250-\mathrm{m}$ downstream the thermal station. Surficial sediment samples were collected at a depth of $0-10 \mathrm{~cm}$ using stainless steel corer at three points (river bed periphery- 2 samples and midriver bed- 1 sample) from each of the sampling locations and composited. The sediment samples were collected into a polythene bag and sealed.

\subsection{Laboratory analysis}

The sediment samples were exposed to open air to dry and thereafter passed through a 2-mm mesh sieve to get rid of plant debris, stones and coarse materials. The sieved sediment samples were ground to powder using pestle and mortar and passed through a 3-mm mesh sieve to collect fine sediment samples required for analysis. The US EPA [42] prescribed method was adopted in acid digestion of the sediment samples. Succinctly, this method consists using $65 \% \mathrm{HNO}_{3} / 37 \% \mathrm{HCl}$ at a ratio of $3: 1 \mathrm{v} / \mathrm{v}$ to digest the sediment samples in a Teflon vessel held in a microwave oven using the appropriate sediment/acid mix ratio. In this study, $15 \mathrm{~mL}$ of acid mix was used in digesting $0.3 \mathrm{~g}$ of sediment sample. The microwave digester (Milestone s.r.l, Italy) was operated in three sequences at 120,150 and $200^{\circ} \mathrm{C}$ for 5,10 and $15 \mathrm{~min}$, respectively. After microwave digestion, deionized water was added and the solution filtered using $0.45-\mu \mathrm{m}$ filter membrane. Additional water was added to make up the volume to $50 \mathrm{~mL}$ and stored in the refrigerator below $4{ }^{\circ} \mathrm{C}$ until required for analysis. The heavy metals $(\mathrm{Cu}$, $\mathrm{Zn}, \mathrm{Cr}, \mathrm{Pb}, \mathrm{Cd}$ ) were analyzed using SensAA GBC flame atomic absorption spectrometer.

\subsection{Quality control}

All the laboratory analysis was carried out in triplicate. Duplicate sample and blank analysis were carried out for the confirmation of method accuracy. The limit of detection (LOD), limit of quantification (LOQ) and recoveries were also determined. The LOD was determined as three times the standard deviation of 10 replicate blank measurements [29]. The LOQ was determined as three times the $L O D$ value. The $L O D$ varied from 0.2 to $0.5 \mu \mathrm{g} / \mathrm{L} ; \mathrm{LOQ}$ varied from 0.5 to $1.5 \mu \mathrm{g} / \mathrm{L}$. The method accuracy and instrument precision were established by the measurement of recoveries using the spiking method for which the heavy metal concentration in spiked and unspiked triplicate sediment samples was determined using the relationship:

$\%$ Recovery $=$ (concentration of heavy metals in spiked sediment sample - concentration of the heavy metals in unspiked sediment sample)/(concentration of the heavy metals in the spiking standard solution supplied by SigmaAldrich). The recoveries which varied from 81 to $104 \%$ are a reflection of the method accuracy, and the relative standard deviation (RSD) ranging from 5 to $11 \%$ is a reflection of the precision which is acceptable. 


\subsection{Pollution assessment and ecological risks due to heavy metals in the sediments}

In this study, the ecological assessments of the sediments as contaminated by heavy metals were assessed using contamination factor (CF), degree of contamination (DC), geochemical accumulation index $\left(I_{\text {geo }}\right)$, pollution load index (PLI) and potential ecological risk index (PERI).

\subsubsection{Contamination factor}

Contamination factor (CF) is a very useful tool used in identifying the contamination level of sediments by heavy metals [14].

$\mathrm{CF}=C_{\text {sediment }} / C_{\text {background }}$

where $C_{\text {sediment }}=$ heavy metal mean concentration in the sediment; $C_{\text {background }}=$ heavy metal concentration in the background.

The background values used in this study are those reported by Hakanson [14].

\subsubsection{Degree of contamination}

The degree of contamination (DC) is estimated by adding the CF for all the heavy metals in the sample as described in Eq. 2.

$\mathrm{DC}=\mathrm{CF}_{1}+\mathrm{CF}_{2}+\mathrm{CF}_{3}+\cdots \mathrm{CF}_{n}$

\subsubsection{Geochemical accumulation index $\left(I_{\text {geo }}\right)$}

The geoaccumulation index $\left(l_{\text {geo }}\right)$ is computed as follows:

$I_{\text {geo }}=\log _{2}\left(C_{n} / 1.5 B_{n}\right)$

where $C_{n}=$ concentration of heavy metals in the sediment; $B_{n}=$ geochemical background value 1.5 is the matrix correction factor for minimizing lithogenic effects [50].

\subsubsection{Pollution load index (PLI)}

Pollution load index (PLI) is a veritable tool used in measuring the extent of pollution of the sediments and is expressed as [36]:

$\mathrm{PLI}=\left(\mathrm{CF}_{1} * \mathrm{CF}_{2} * \mathrm{CF}_{3} * \cdots \mathrm{CF}_{n}\right)^{1 / n}$

where $\mathrm{CF}=$ contamination factor; $n=$ number of heavy metals in the sediment sample.

\subsubsection{Potential ecological risk index (PERI)}

The potential ecological risk index (PERI) of the heavy metals in the sediments was derived from summing the potential ecological risk factor (PERF) of the individual heavy metals.

$\mathrm{PERF}=\mathrm{CF} * \mathrm{TRC}$

where $\mathrm{CF}=$ contamination factor.

TRC = toxic response coefficient for a given heavy metal. This study adopted the TRC reported in Hakanson [14]. TRC is actually an indication of a heavy metal's toxicity and ecological sensitivity; hence, the higher the coefficient, the more toxic and ecological sensitivity [13].

$\mathrm{PERI}=\mathrm{PERF}_{1}+\mathrm{PARF}_{2}+\mathrm{PERF}_{3}+\cdots \mathrm{PERF}_{n}$

\subsection{Human health risk exposure to heavy metals in the sediments}

\subsubsection{Non-carcinogenic risks of exposure to heavy metals as a result of ingestion of sediment and dermal contact}

Hazard quotient $(\mathrm{HQ})$ and hazard index $(\mathrm{HI})$ were used in estimating the non-carcinogenic risks of exposure to heavy metals in the sediments according to Eqs. 7 and 8.

$\mathrm{HQ}=D / \mathrm{RfD}$

$\mathrm{HI}=\mathrm{HQ}_{1}+\mathrm{HQ}_{2}+\mathrm{HQ}_{3}+\mathrm{HQ}_{4}+\mathrm{HQ}_{5}$

where $D=$ exposure dose; $R f D=$ reference dose for the heavy metals; $\mathrm{HQ}_{1}$ to $\mathrm{HQ}_{5}$ are the hazard quotients for each of the heavy metals.

The equations for computing the chronic exposure dose of the sediments via entry routes such as inadvertent oral ingestion and dermal contacts and definitions of the terms in the equations are as reported in Ugochukwu et al. [38].

The values of the parameters employed in determining exposure dose of the heavy metals in sediments for an adult considering chronic exposure duration of 35 years are as presented in Table 1.

\subsection{Statistical method}

Analysis of variance (ANOVA) was employed in data analysis using Minitab version 18 statistical software. 
Table 1 Values of the parameters for determining exposure dose

\begin{tabular}{|c|c|}
\hline Parameters & Values \\
\hline $\mathrm{IR}_{\mathrm{S}}$ (soil ingestion rate) & $0.02 \mathrm{~g} /$ day \\
\hline EF (exposure frequency) 1 event per day & 1 \\
\hline ET (exposure term) ${ }^{\mathrm{a}}$ & 0.042 \\
\hline BW (body weight) & 70 kg \\
\hline Exposed skin surface area (hands) $\left(S_{H}\right)$ & $430 \mathrm{~cm}^{2}$ \\
\hline Exposed skin surface area (arms) $\left(\mathrm{SA}_{\mathrm{A}}\right)$ & $890 \mathrm{~cm}^{2}$ \\
\hline Exposed skin surface area (legs) $\left(S A_{L}\right)$ & $1690 \mathrm{~cm}^{2}$ \\
\hline Soil loading to skin hands $\left(\mathrm{SL}_{\mathrm{H}}\right)$ & $1 \times 10^{-4} \mathrm{~g} / \mathrm{cm}^{2} /$ event \\
\hline $\begin{array}{l}\text { Soil loading to skin arms and legs }\left(\mathrm{SL}_{\mathrm{A}} \text { and }\right. \\
\left.\mathrm{SL}_{\mathrm{L}}\right)\end{array}$ & $1 \times 10^{-5} \mathrm{~g} / \mathrm{cm}^{2} /$ event \\
\hline $\mathrm{RAF}_{\text {git }}$ & 1 \\
\hline $\mathrm{RAF}_{\text {skin }}$ & 0.1 \\
\hline CF (unit correction factor) & $0.001 \mathrm{~L} / \mathrm{cm}$ \\
\hline
\end{tabular}

${ }^{a}$ Exposure term is assumed to be $1 \mathrm{~h}$ a day, 7 days a week, 52 weeks a year, exposure period of 35 years [16]. ET $=\left(1 / 24^{*} 7 / 7^{*} 52 / 52^{*} 35 / 3\right.$ 5) $=0.125$

Table 2 Concentration of the heavy metals in the various sampling locations of the Oji River sediments as sampled in October 2017 and January 2018

\begin{tabular}{|c|c|c|c|c|}
\hline \multirow[t]{2}{*}{ Heavy metals } & \multicolumn{4}{|c|}{ Location } \\
\hline & $A$ & $B$ & $C$ & $D$ \\
\hline \multicolumn{5}{|c|}{ Concentration values $(\mathrm{mg} / \mathrm{Kg})$ for October 2017} \\
\hline $\mathrm{Pb}$ & 28.4 & 124 & 251 & 14.3 \\
\hline $\mathrm{Cu}$ & 6.5 & 14.6 & 8.1 & 13.8 \\
\hline $\mathrm{Cr}$ & 28.1 & 380 & 85.4 & 56.3 \\
\hline $\mathrm{Zn}$ & 14 & 321 & 43.5 & 130.4 \\
\hline $\mathrm{Cd}$ & 3.2 & 20.5 & 0.01 & 1.6 \\
\hline \multicolumn{5}{|c|}{ Concentration values $(\mathrm{mg} / \mathrm{Kg}$ ) for January 2018} \\
\hline $\mathrm{Pb}$ & 76 & 75 & 64.1 & 128.2 \\
\hline $\mathrm{Cu}$ & 50.1 & 525 & 123.5 & 210 \\
\hline $\mathrm{Cr}$ & 35.4 & 356 & 40.8 & 123.4 \\
\hline $\mathrm{Zn}$ & 41.7 & 661 & 41 & 272.1 \\
\hline $\mathrm{Cd}$ & 3.5 & 10.5 & 3.2 & 5.2 \\
\hline
\end{tabular}

Values are presented as mean

\section{Results and discussion}

\subsection{Concentration of the heavy metals in sediment and water column}

The concentration of the heavy metals in the sediments of Oji River as monitored (within the period of October 2017 and January 2018) to ascertain the effects of the two major anthropogenic activities, namely abattoir and Oji River Power Station, is as presented in Table 2.
The concentration of the heavy metals in the sediments is highest around the abattoir (location $B$ ), especially for $\mathrm{Zn}, \mathrm{Cr}, \mathrm{Cu}$ and $\mathrm{Cd}$ (Table 4), indicating input of these metals into the sediments from the activities of the abattoir. The concentrations of these heavy metals for location $B$ are not only just higher but also statistically significantly different from those of the other locations for both rainy and dry seasons. During our sampling campaign, it was observed that cow meat sellers who butcher cows at the abattoir make use of waste car tires to burn off the hairy portion of the cow skin in order to prepare the hide and skin for consumption by local residents. Piles of residue of the burnt tires are usually on site at the abattoir. Given that tires contain heavy metals including those covered in this study, these residues from burnt tires are veritable sources of the heavy metals $[6,22,32]$. Therefore, elevated concentration of $\mathrm{Zn}, \mathrm{Cr}, \mathrm{Cu}$ and $\mathrm{Cd}$ around the abattoir at location $B$ is most likely to be due to the waste tires used as fuel for burning off the hairy skin of cows at the abattoir.

The concentration of lead in the sediments of Oji River around the abattoir is higher than the levels reported in the rivers of some regions of the world such as Awash River Basin in Ethiopia, Lijiang River in China, Dongting Lake in China, Korotoa River in Bangladesh and River Benue in Nigeria, whereas it is lower than the levels reported for Shur River in Iran, Gomti River in India, Axos River in Greece, Danube River in Germany and Tigris River in Turkey $[1,5,19-21,23,34,44,46,49]$. The lead concentration in Oji River sediment of $99.5 \mathrm{mg} / \mathrm{kg}$ is higher than Canadian Council of Ministers of the Environment (CCME) probable effect level (PEL) of $91.3 \mathrm{mg} / \mathrm{kg}$ [4], indicating probable ecological risk. Also, the concentrations of chromium (368 mg/kg), copper ( $270 \mathrm{mg} / \mathrm{kg})$, zinc $(491 \mathrm{mg} / \mathrm{kg})$ and cadmium $(15.5 \mathrm{mg} / \mathrm{kg})$ in the sediment of Oji River exceed the CCME PEL of $90,197,315$ and $15.5 \mathrm{mg} / \mathrm{kg}$, respectively, indicating possible ecological impairment due to these heavy metals.

\subsection{Contamination factor, degree of contamination, geochemical accumulation index, pollution load index and potential ecological risk index}

The contamination factor and degree, geochemical accumulation index, pollution load index and potential ecological risk index of the heavy metals in the sediment of Oji River are as presented in Table 3.

The contamination factor of the heavy metals in the sediments of Oji River at location $A$ indicates that only cadmium poses considerable contamination with $\mathrm{CF}>3.0$ but $<6.0$, whereas the rest of the other heavy metals with $\mathrm{CF}<1.0$ pose low contamination in the sediments [14]. In location $B$, during the wet season, Cu poses low contamination, whereas $\mathrm{Pb}$ and $\mathrm{Zn}$ pose moderate contamination. 
Table 3 Sediment ecological risk values

\begin{tabular}{|c|c|c|c|c|c|c|c|c|c|c|c|c|c|c|c|c|c|c|c|c|}
\hline \multirow[t]{3}{*}{ Heavy metals } & \multicolumn{20}{|c|}{ Location } \\
\hline & \multicolumn{5}{|l|}{$A$} & \multicolumn{5}{|l|}{$B$} & \multicolumn{5}{|l|}{$C$} & \multicolumn{5}{|l|}{$D$} \\
\hline & CF & $C D$ & $I_{\text {geo }}$ & PLI & PERI & CF & $C D$ & $I_{\text {geo }}$ & PLI & PERI & CF & $C D$ & $I_{\text {geo }}$ & PLI & PERI & CF & $C D$ & $I_{\text {geo }}$ & PLI & PERI \\
\hline \multicolumn{21}{|c|}{ Values for wet season } \\
\hline $\mathrm{Pb}$ & 0.4 & 4.1 & -1.9 & 0.3 & 99 & 1.8 & 29 & 0.2 & 2.4 & 636 & 3.5 & 5 & 1.3 & 0.3 & 21.2 & 0.2 & 3.5 & -2.9 & 0.5 & 52 \\
\hline $\mathrm{Cu}$ & 0.1 & & -3.5 & & & 0.3 & & -2.4 & & & 0.2 & & -3.2 & & & 0.3 & & -2.4 & & \\
\hline $\mathrm{Cr}$ & 0.3 & & -2.3 & & & 4.2 & & 1.5 & & & 0.9 & & -0.7 & & & 0.6 & & -1.3 & & \\
\hline $\mathrm{Zn}$ & 0.1 & & -4.2 & & & 1.8 & & 0.3 & & & 0.2 & & -2.6 & & & 0.7 & & -1.0 & & \\
\hline $\mathrm{Cd}$ & 3.2 & & 1.1 & & & 21 & & 3.8 & & & 0.01 & & -7.2 & & & 1.6 & & 0.1 & & \\
\hline \multicolumn{21}{|c|}{ Values for dry season } \\
\hline $\mathrm{Pb}$ & 1.1 & 6.2 & -0.5 & 0.8 & 116 & 1.1 & 30 & -0.5 & 4.5 & 385 & 0.9 & 7.3 & -0.7 & 1.0 & 114 & 1.8 & 14 & 0.3 & 2.4 & 190 \\
\hline $\mathrm{Cu}$ & 1.0 & & -0.6 & & & 11 & & 2.8 & & & 2.5 & & 0.7 & & & 4.2 & & 1.5 & & \\
\hline $\mathrm{Cr}$ & 0.4 & & -1.9 & & & 4 & & 1.4 & & & 0.5 & & -1.7 & & & 1.4 & & -0.1 & & \\
\hline $\mathrm{Zn}$ & 0.2 & & -2.7 & & & 3.8 & & 1.3 & & & 0.2 & & -2.7 & & & 1.6 & & 0.1 & & \\
\hline $\mathrm{Cd}$ & 3.5 & & 1.2 & & & 11 & & 2.8 & & & 3.2 & & 1.1 & & & 5.2 & & 1.8 & & \\
\hline
\end{tabular}

CF contamination factor; $C D$ degree of contamination; $I_{\text {geo }}$ geochemical accumulation index; $P L /$ pollution load index; $P E R I$ potential ecological risk index

Table 4 Human health exposure using hazard index

\begin{tabular}{lll}
\hline Location & Sediments & \\
\cline { 2 - 3 } & Hazard index-wet season & $\begin{array}{l}\text { Hazard } \\
\text { index-dry } \\
\text { season }\end{array}$ \\
\hline$A$ & 0.005 & 0.006 \\
$B$ & 0.05 & 0.04 \\
$C$ & 0.009 & 0.007 \\
$D$ & 0.006 & 0.02 \\
\hline
\end{tabular}

However, $\mathrm{Cr}$ and $\mathrm{Cd}$ pose considerable and very high contamination to the sediments, respectively, at respective CF of 4.2 and 21 (Table 3). CF $>6.0$ implies very high contamination [14]. It is therefore evident that the main heavy metal contaminants of the sediments in the wet season for location $B$ are chromium and cadmium. During the dry season, only lead is of moderate contamination, whereas the rest are either of considerable or very high contamination. $\mathrm{Cr}$ and $\mathrm{Zn}$ are of considerable contamination, whereas $\mathrm{Cu}$ and $\mathrm{Cd}$ are of very high contamination. This study has revealed that $\mathrm{Cr}$ and $\mathrm{Cd}$ are of considerable and very high contamination in the sediments, respectively, for all seasons for location $B$ of the Oji River sediments. For location $\mathrm{C}$, only $\mathrm{Pb}$ poses considerable contamination in the wet season, whereas $\mathrm{Cu}$ and $\mathrm{Cd}$ pose moderate and considerable contamination, respectively. There is only moderate contamination of the sediments coming from $\mathrm{Cd}$ in the wet season for location $\mathrm{D}$, whereas $\mathrm{Pb}, \mathrm{Cr}$ and $\mathrm{Zn}$ pose moderate contamination in the dry season with $\mathrm{Cd}$ and $\mathrm{Cu}$ posing considerable contamination.
During the wet season, the degree of contamination (CD) for locations $A, C$ and $D$ in each case is $<7.0$, indicating low degree of contamination, whereas for location $B$ with $C D=29$ which is $>28$, the degree of contamination is very high [28]. However, during the dry season, location $A$ with $C D<7$ indicates low degree of contamination, whereas location $C$ with CD 7.3 but $<14$ indicates moderate degree of contamination [28]. Location $D$ with $C D=14$ is taken to be of considerable degree of contamination, whereas location $B$ with $C D=30$ is of very high degree of contamination. This study therefore reveals that during the wet and dry season, the degree of contamination is very high for location $B$. The degree of contamination for location $A$ in all seasons is low, whereas locations $C$ and $D$ will have moderate and considerable degree of contamination only in dry season.

The geochemical accumulation index $\left(I_{\text {geo }}\right)$ classification scheme proposed by Muller [25] and applied by other researchers such as Sharifi et al. [33] was used in interpreting the $I_{\text {geo }}$ data in this work. The scheme is as follows:

Class 0 (uncontaminated): $I_{\text {geo }} \leq 0$; Class 1 (uncontaminated to moderately contaminated): $0<I_{\text {geo }}<1$; Class 2 (moderately contaminated): $1<I_{\text {geo }}<2$; Class 3 (moderately to heavily contaminated): $2<I_{\text {geo }}<3$; Class 4 (heavily contaminated): $3<I_{\text {geo }}<4$; Class 5 (heavily contaminated to extremely contaminated): $4<I_{\text {geo }}<5$; and Class 6 (extremely contaminated): $5<I_{\text {geo }}$.

The $I_{\text {geo }}$ for $\mathrm{Pb}, \mathrm{Cr}, \mathrm{Cu}$ and $\mathrm{Zn}$ in location $A$ for the wet and dry seasons is less than 0 , indicating that the sediment is not contaminated with these heavy metals, but the $I_{\text {geo }}$ for cadmium in both wet and dry seasons is $>1$ but $<2$, indicating moderate contamination. 
The $I_{\text {geo }}$ for $\mathrm{Pb}$ in location $B$ during the wet season indicates uncontaminated to moderately contaminated, whereas during the dry season, it becomes uncontaminated. $I_{\text {geo }}$ for $\mathrm{Cu}$ in the same location indicates uncontaminated in wet season but moderately to heavily contaminated in dry season. There is moderate contamination coming from $\mathrm{Cr}$ for all seasons, whereas for $\mathrm{Zn}$ it is uncontaminated to moderately contaminated in wet season and moderately contaminated in dry season. In the wet season, the $I_{\text {geo }}$ for cadmium indicates heavily contaminated, whereas during the dry season it is moderately to heavily contaminated.

The $I_{\text {geo }}$ of $\mathrm{Pb}$ in location $C$ in the wet season indicates moderately contaminated, whereas the $I_{\text {geo }}$ for the rest of the other heavy metals in the same wet season indicates uncontaminated. For the dry season, the $I_{\text {geo }}$ of $\mathrm{Cu}$ indicates uncontaminated to moderately contaminated, whereas it indicates moderately contaminated for $\mathrm{Cd}$. There is no contamination coming from $\mathrm{Cr}, \mathrm{Zn}$ and $\mathrm{Pb}$ in the dry season.

For location $D$, the $I_{\text {geo }}$ for $\mathrm{Pb}, \mathrm{Cr}, \mathrm{Zn}$ and $\mathrm{Cu}$ in the wet season indicates uncontaminated, whereas for $\mathrm{Cd}$, it is uncontaminated to moderately contaminated. In the dry season, there is no contamination coming from $\mathrm{Cr}$, whereas it is uncontaminated to moderately contaminated for $\mathrm{Pb}$ and $\mathrm{Zn}$ and moderately contaminated for both $\mathrm{Cu}$ and $\mathrm{Cd}$.

The utility of $I_{\text {geo }}$ is derived from its ability to indicate possible anthropogenic input. As can be observed in location $B$ where for all seasons, Cr occurred at a level of 'moderately contaminated' and cadmium at a level of either moderately to heavily contaminated or heavily contaminated, indicating that these two heavy metals are released into the aquatic environment from anthropogenic sources most probably the abattoir.

Pollution load index (PLI) data in this study were interpreted according to the scheme reported by Tomlinson et al. [36] and applied by Sharifi et al. [33] and Vu et al. [45] as follows:

$\mathrm{PLI}=\mathrm{O}$ : not polluted; $\mathrm{PLI}<1$ : unpolluted; $\mathrm{PLI} \geq 1$ : polluted. The higher the PLI, the higher the pollution. It therefore follows that the sediments of location $A$ for all seasons are unpolluted with the heavy metals, whereas locations $C$ and $D$ are unpolluted during the wet season but polluted during the dry season with location $D$ being more polluted than location $C$. Location $B$ is polluted in all the seasons but more polluted in the dry season. Using PLI, this study demonstrates that location $B$ is the most polluted location.

The potential ecological risk index (PERI) in this study was interpreted using the scheme reported by Hakanson [14] as follows:
$\mathrm{PERI}<110$ : low risk; $110 \leq \mathrm{PERI}<200$ : moderate risk; $200 \leq \mathrm{PERI}<400$ : considerable risk; and $400 \leq \mathrm{PERl}$ : very high risk.

PERI for the sediments at locations $A, C$ and $D$ during the wet season is $<110$, indicating low ecological risk, but during the dry season, the ecological risk becomes moderate as PERI is $>110$ but $<200$. For location $B$ during the dry season, the ecological risk is considerable at PERI of 385 , whereas the ecological risk is very high during the wet season as the $P E R I=636$. This study therefore demonstrates that the aquatic biota within this location $B$ is at a risk of biological impairment arising from the toxic effect of the heavy metals.

\subsection{Non-carcinogenic risk exposure to heavy metals in sediments}

The human exposure to the heavy metals as assessed using hazard index is presented in Table 4.

The human exposure to heavy metals via inadvertent ingestion of the sediment and dermal contact as assessed employing hazard index ( $\mathrm{HI})$ indicates that the non-carcinogenic health risk is very low for all locations and all seasons as the $\mathrm{HI} \ll 1$ in all cases. This implies that the noncarcinogenic risks associated with contact and ingestion of the sediment as the locals use the water are insignificant.

\section{Conclusion}

This study having assessed the heavy metal contamination of Oji River sediment in addition to the ecological and human health risk exposure found that cadmium contamination of the sediment is most profound followed by chromium and lead. The most polluted location is that within the location of the abattoir, the abattoir was found to contribute to the heavy metal input to the sediment due to the burning of waste tires. The geochemical accumulation index, contamination degree, pollution load index and potential ecological risk index all point to the fact that the location within the abattoir has the sediments highly polluted with heavy metals. There is insignificant non-carcinogenic risk of exposure by humans to the heavy metals in all the locations of as the $\mathrm{HI}$ is far less than unity. The heavy metal pollution of the sediments poses a great risk to the survival of benthic organisms and other biota that inhabits the water column.

The use of waste tires as fuel for burning off cows' hairy parts in preparation of the hide and skin for consumption should be discontinued as these appears to be the major source of heavy metal input into the river. 
Acknowledgements We express appreciation for all the assistance received in the course of this study from the SHELL Centre for Environmental Management and Control of the University of Nigeria.

\section{Compliance with ethical standards}

Conflict of interest The authors declare that they have no conflict of interest.

\section{References}

1. Adamu Cl, Nganje TN (2009) Assessment of heavy metals pollution in sediments and surface water of river Benue, Makurdi, Nigeria. J Appl Sci Eng Technol 9:1-10

2. Alghamdi BA, Mannoubi IE, Zabin SA (2018) Heavy metals' contamination in sediments of Wadi Al-Al-Aqiq water reservoir dam at Al-Baha region, KSA: their identification and assessment. Hum Ecol Risk Assess Int J. https://doi.org/10.1080/10807 039.2018.1451746

3. Bradulience J, Sveikauskaite I (2017) Soil surface pollution with heavy metals caused by coal-fired boilers. In: Environmental engineering 10th international conference, Vilnius Gediminas Technical University. https://doi.org/10.3846/enviro.2017.010

4. CCME (Canadian Council of Ministers of Environment) (1999) Canadian sediment quality guidelines for the protection of aquatic life CCME-EPC-98E. Protocol for the derivation of Canadian sediment quality guidelines for the protection of aquatic life

5. Dirbaba NB, Yan X, Wu H, Colebrooke LL, Wang J (2018) Occurrences and ecological risk assessment of heavy metals in surface sediments from Awash River Basin, Ethiopia. Water 10:535-548

6. Downard JM (2014) Particulate emissions of tire combustion. MS (Master of Science) thesis, University of lowa. http://ir.uiowa .edu/etd/4615. Accessed 14 July 2018

7. Dudgeon D, Arlington AH, Gessner MO, Kawabata ZI, Knowler DJ, Leveque C, Sullivan CA (2006) Freshwater biodiversity: importance, threats, status and conservation challenges. Biol Rev 81(2):163-182

8. Egboka BCE, Okpoko El (1984) Gully erosion in the Agulu Nanka region of Anambra State, Nigeria. In: Challenges in African hydrology and water resources (proceedings of Harare symposium, IAHS. Publication no. 144, pp 335-347)

9. Esmaeilzadeh M, Karbassi A, Moattar F (2016) Assessment of metal pollution in the Anzali wetland sediments using chemical partitioning method and pollution indices. Acta Oceanol Sin 35:28-36

10. Ferati F, Kerolli-Mustafa M, Kraja-Ylli A (2015) Assessment of heavy metal contamination in water and sediments of Trepca and Sitnica rivers, Kosovo, using pollution indicators and multivariate cluster analysis. Environ Monit Assess 187:338

11. Flues M, Moraes V, Mazzilli BP (2002) The influence of a coal-fired power plant operation on radionuclide concentrations in soil. $J$ Environ Radioact 63:285-294

12. Gaur VK, Gupta SK, Prandey SD, Gopal K, Misra V (2005) Distribution of heavy metals in sediment and water of River Gomti. Environ Monit Assess 102:419-433

13. Guo W, Liu X, Liu Z, Li G (2010) Pollution and potential ecological risk evaluation of heavy metals in the sediments around Dongjiang Harbour, Tianjin. Proc Environ Sci 2:729-736

14. Hakanson $L$ (1980) An ecological risk index for aquatic pollution control of sediments: ecological approach. Water Res 14:975-1000
15. Hay C, Franti T, Marx D, Peters E, Hesse L (2008) Macroinvertebrate drift density in relation to abiotic factors in the Missouri River. Hydrobiologia 598(1):175-189

16. Health Canada (2010) Federal contaminated site risk assessment in Canada, part V: guidance on human health detailed quantitative risk assessment for chemicals. www.healthcanada.gc.ca. Accessed Apr 2017

17. Huang X, Hu J, Qin F, Quan W, Cao R, Fan M, Wu X (2017) Heavy metal pollution and ecological assessment around the Jinsha Coal-Fired Power Plant (China). Int J Environ Res Public Health 14:1589-1602

18. IRIS (Integrated Risk Information System) (2018) https://cfpub .epa.gov/ncea/iris2/atoz.cfm. Accessed July 2018

19. Islam MS, Ahmed MK, Raknuzzaman M, Al-Mamun MH, Islam MK (2015) Heavy metal pollution in surface water and sediment: $A$ preliminary assessment of an urban river in a developing country. Ecol Indic 48:282-291

20. Karageorgis AP, Nikolaidis NP, Karamanos H, Skoulikidis N (2003) Water and sediment quality assessment of the Axios River and its coastal environment. Cont Shelf Res 23:1929-1944

21. Karbassi AR, Monavari SM, Nabi Bidhendi GR, Nouri J, Nematpour K (2008) Metal pollution assessment of sediment and water in the Shur River. Environ Monit Assess 147:107-116

22. Lemieux PM, Ryan JV (1993) Characterization of air pollutants emitted from a simulated scrap tire fire. Air Waste 43(8):1106-1115

23. Li F, Huang J, Zeng G, Yuan X, Li X, Liang J, Wang X, Tang X, Bai $B$ (2013) Spatial risk assessment and sources identification of heavy metals in surface sediments from the Dongting Lake, Middle China. J Geochem Explor 132:75-83

24. Machado CS, Fregomesi BM, Alves RIS, Tomani KAA, Sierra J, Martins BS, Celere BS, Mari M, Schuhmacher M, Nadal M, Domingo $\mathrm{Jl}$, Segura-Munoz S (2017) Health risks of environmental exposure to metals and herbicides in the Pardo River, Brazil. Environ Sci Pollut Res 24(25):20160-20172. https://doi.org/10.1007/ S11356-017-9461-z

25. Muller G (1969) Index of geoaccumulation in sediments of the Rhine River. GeoJournal 2:108-118

26. Naveeduallah MZH, Hasmi MZ, Yu C, Shen H, Duan D, Shen C, Lou L, Chen Y (2014) Concentrations and human health risk assessment of selected heavy metals in surface water of the Siling Reservoir Watershed in Zhejiang Province China. Pol J Environ Stud 23(3):801-811

27. Obaje NG (2009) Geology and mineral resources of Nigeria. Springer, Dordrecht, $\mathrm{p} 211$

28. Pedersen F, Bjornestad E, Andersen HV, Kjolholt J, Poll C (1998) Characterization of sediments from Copenhagen Harbour by use of biotests. Water Sci Technol 37:233-240

29. Pekey H, Karakas D, Bakoglu M (2004) Source apportionment of trace metals in surface waters of a polluted stream using multivariate statistical analysis. Mar Pollut Bull 49:809-818

30. Reyment RA (1965) Aspect of geology of Nigeria. Ibadan University Press, Ibadan, p 126

31. Salomons W, Forstner U (1984) Metals in the hydrocycle. Springer, Berlin

32. Shakya PR, Shrestha P, Tamrakar S, Bhattarai P (2006) Studies and determination of heavy metals in waste tyres and their impacts on the environment. Pak J Anal Environ Chem 7(2):70-76

33. Sharifi Z, Hossaini SMT, Renella G (2016) Risk assessment for sediment and stream water polluted by heavy metals released by a municipal solid waste composting plant. J Geochem Explor 169:202-210

34. Singh KP, Malik A, Sinha S, Singh VK, Murthy RC (2005) Estimation of source of heavy metal concentration in sediments of Gomti River (India) using principal component analysis. Water Air Soil Pollut 166:321-344 
35. Sobotka MJ, Phelps QE (2017) A comparison of main and side channel physical and water quality metrics and habitat complexity in the middle Mississippi river. River Res Appl 33:879-888

36. Tomlinson DL, Wilson JG, Harris CR, Jeffrey DW (1980) Problems in the assessment of heavy-metal levels in estuaries and the formation of a pollution index. Helgol Meeresunters 33:566-575

37. Ugochukwu UC, Ochonogor A (2018) Groundwater contamination by polycyclic aromatic hydrocarbon due to diesel spill from a telecom base station in a Nigerian City: assessment of human health risk exposure. Environ Monit Assess 190:249-252

38. Ugochukwu UC, Ochonogor A, Jidere CM, Agu C, Nkoloagu F, Ewoh J, Okwu-Delunzu VU (2018) Exposure risks to polycyclic aromatic hydrocarbons by humans and livestock (cattle) due to hydrocarbon spill from petroleum products in Niger-delta wetland. Environ Int 115:38-47

39. U.S. EPA (United States Environmental Protection Agency) (1993) Groundwater contamination. A guide for small communities EPA/625/R-93/002

40. U.S. EPA (1997) Exposure Factors Handbook. U.S. Environmental Protection Agency, Washington, DC, EPA/600/P-95/002F a-c

41. U.S. EPA (United States Environmental Protection Agency) (2005) Guideline for carcinogen risk assessment. Risk assessment forum, USEPA Washington D.C. EPA 630/P-03/001B

42. US EPA (2007) Method 3051a: microwave assisted acid dissolution of sediments, sludges, soils, and oils. Revision 1. United States Environmental Protection Agency, Washington DC

43. U.S. EPA (2011) Exposure factors handbook 2011 edition (final), office of research and development. National Centre for Environmental Assessment, Washington DC

44. Varol M, Sen B (2012) Assessment of nutrient and heavy metal contamination in surface water and sediments of the upper Tigris River, Turkey. Catena 92:1-10
45. Vu CT, Lin C, Nguyen KA, Shern C-C, Kuo Y-M (2018) Ecological risk assessment of heavy metals sampled in sediments and water of the Houjing River, Taiwan. Environ Earth Sci 77:388-398

46. Woitke P, Wellmitz J, Helm D, Kube P, Lepom P, Litheraty P (2003) Analysis and assessment of heavy metal pollution in suspended solids and sediments of the river Danube. Chemosphere 51:633-642

47. Wu B, Zhang $Y$, Zhang XX, Cheng SP (2010) Health risk from exposure of organic pollutants through drinking water consumption in Nanjing, China. Bull Environ Contam Toxicol 84:46-50

48. Wu S, Peng S, Zhang X, Wu D, Luo W, Zhang T, Zhou S, Yang G, Wan H, Wu L (2015) Levels and health risk assessments of heavy metals in urban soils in Dongguan, China. J Geochem Explor 48:71-78

49. Xu D, Wang Y, Zhang R, Guo J, Zhang W, Yu K (2016) Distribution, speciation, environmental risk, and source identification of heavy metals in surface sediments from the karst aquatic environment of the Lijiang River, Southwest China. Environ Sci Pollut Res 23:9122-9133

50. Yi Y-J, Sun J, Tang C-H, Zhang S-H (2016) Ecological risk assessment of heavy metals in sediment in the upper reach Yangtze River. Environ Sci Pollut Res 45:45. https://doi.org/10.1007/s1135 6-016-6296-y

Publisher's Note Springer Nature remains neutral with regard to jurisdictional claims in published maps and institutional affiliations. 